\title{
THE POTENTIAL IMPACT OF BLOCKCHAINS ON CORPORATE GOVERNANCE: A SURVEY ON SHAREHOLDERS' RIGHTS IN THE DIGITAL ERA
}

\author{
Véronique Magnier \\ Patrick Barban ${ }^{* *}$
}

\begin{abstract}
Blockchains offer a revolutionary application of cryptography and information technology to old financial record-keeping issues while forging great hopes with regard to lower cost, greater liquidity, more accurate record-keeping, and transparency of ownership. There is also an increasing demand from individual companies to employ blockchains in their activities as some stock exchanges see blockchain technology as a new method for trading corporate equities and tracking their ownership.
\end{abstract}

At the same time, an expanded use of this new technology may introduce new risks on the market and lead to far-reaching changes in corporate governance. The end of anonymity is one of these issues but other corporate governance issues may be raised. While EU regulation regarding shareholders' rights is moving forward, these risks have not been taken into account so far: the potential impact blockchains may have on shareholders' protection in the EU Market and elsewhere is absent. European institutions seem to have dodged consideration of this impact.

This paper evaluates the potential implication blockchains may have in a near future, assessing whether and how this new technology may modify the balance of power among managers, institutional investors, small shareholders, proxy advisors and other parties involved in corporate governance.

KEYWORDS: blockchains, corporate governance, shareholders, managers, proxy advisors, check and balance, voting rights, EU Directive, third parties.

\footnotetext{
* Paris-Sud/Paris-Saclay University, Director of Insitute Droit Ethique Patrimoine; veronique.magnier@u-psud.fr

** Le Havre - Normandie University; patrick.barban@univ-lehavre.fr
} 


\section{INTRODUCTION}

Soon, BC technology may offer a significant alternative to classical ownership ledgers, an important topic which is worth dealing with on a legal perspective. In the last years, the Blockchain technology has grown in reputation, trending in the press and on social media. As a result, more and more companies rely on that technology in order to provide new products and services. The Fintech industry illustrates the use of the Blockchain technology to provide enhanced payment, banking and financial services ${ }^{1}$. To facilitate the implementation of these new services, some actors require changes in regulation. Some even argue that the rise of the Blockchain is likely to put an end to the need of any legal system, quoting Lawrence Helsing without fully understanding him², under the famous "Code is Law" and its derivative, Lex Cryptographica". No more judges and no more central authorities needed under a transparent, secured and autonomous organization ${ }^{5}$. Conversely, voices are rising to claim that the Blockchain is only a trend in social media and should soon vanish, as is the fate of many other trends before.

On a more moderate tone, we think on the contrary that the Blockchain is a new and promising technology that will only slightly alter corporate law. It is not, however, a new paradigm. On the one hand, the technology increases

For instance, the Depositary Trust and Clearing Corporation (DTTC), the leading company in Post-trade services has announced the launch of a Credit Default Swap register based on distributed Ledger Technology.

2 As the author explains in his paper that the architecture of the code is able to reflect the value - or the absence of value - of a society, protecting or denying protection for privacy or other fundamental rights.

3 [https://harvardmagazine.com/2000/01/code-is-law-html], accessed on 28/08/2018.

4 De Filippi P., Wright A., Blockchain and the Law: The Rule of Code, Harvard University Press, Cambridge Massachusetts, 2018, p. 32, p. 49 and p. 193: Lex Cryptographica is the idea that the best regulator in a technological infrastructure is the code of that infrastructure itself. The use of the technology can be shaped in order to forbid technically unwanted use of the technology (as illegal music downloading), thus lowering the need of human regulation.

5 De Fillippi P., Wright A., Ibid., p. 194 : the authors express the idea that "Technical rules could increasingly assume the same role and functionality as legal rules". The authors advocate the use of technology to achieve more predictable rules as opposed to law written in natural language. But these advantages must be carefully balanced. First, the implementation of the rules into the code would forbid a user to commit a breach of the law. the virtue of perfect predictability is minored by the fact that no adjustment can be made in order to ensure the rights of the user to their particular situation. Second and more importantly, such a system is dangerous in regards to the respect of fundamental rights. A free state is is based on a liberty principle where the citizen are free to act but would suffer the punishment for a breach of law. Liberty means fundamentally an ex-post control system, not an ex-ante system where liberty would be immediately hampered by the code. 
efficiency in exchanges and group organization, especially in the organization of corporations. On the other hand, it could be detrimental to certain aspects of the Law and could facilitate fraud and money laundering. As many technologies before, especially the Internet, blockchain will bring forth legal changes only if its use is deemed beneficial.

But what is a Blockchain? Blockchain technology has been implemented by a person or group called "Satoshi Nakamoto", alongside with a paper explaining the technical aspects of the technology and its purpose: "Bitcoin: A Peer-toPeer Electronic Cash System". The main purpose of the Bitcoin is to settle a global database permitting the exchange of a new digital currency called "the Bitcoin". The decentralized characteristic of the technology should bring an end to the need for a Third-Party such as a central bank ${ }^{7}$. A decade later, a new system called Ethereum was born with new functionalities such as a better use of Tokens and the implementation of "Smart Contract" enabling the coding of a growing number of applications ${ }^{8}$. Rather than a new technology, it is the improvement of the former as it will be itself the root of further improvements.

The Blockchain system works as a Peer-to-Peer system, a system where all participants act as a supplier and consumer of information, as opposed to a server-based system where a central server furnishes the information to all clients. The system by itself possesses a certain number of characteristics, in order to establish an autonomous system, which does not rely on a central authority. The Blockchain needs to combine both a high level of security based on cryptography and the absence of third-party acting as central authority ${ }^{9}$. To settle an efficient and autonomous system, the Blockchain relies on nodes: basically, computing power used to create hash codes to link each new block to the chain. This activity is called "mining" as it allows the owners of the nodes to collect bitcoins or other tokens ${ }^{10}$. It is not the purpose of this paper to expla-

6 [https://bitcoin.org/bitcoin.pdf], accessed on 28/08/2018.

7 The Bitcoin was a response to the financial crisis of 2008 resulting in a trust-crisis toward central authorities and the banking system.

8 [https://github.com/ethereum/wiki/wiki/White-Paper], accessed on 28/08/2018.

9 Before the Bitcoin they were digital currencies. But to avoid the issue of double spending, they relied on a central authority. As a matter of fact, a digital currency is merely a sum of bits. An actor who own 5 of them can send 5 to a friend and 5 to another friend. No one is able to know that this actor has effectively spend its 5 coins. Therefore, he was able to send 10 coins. He has committed a fraud, spending more coins that he owns and created inflation. It is the basic issue of forged money. Hence the need of a central authority to whom all the transactions will be send for regulation.

10 Each transaction is put in a block which is chained to the previous block. That block use the hash code of the previous one (acting as a timestamp) and will get its own hash code based on the transactions that are coded inside. To code it, several node proceeds by creating the 
in how the system function since it has already been explained ${ }^{11}$. Nevertheless, the fundamental purpose of a Blockchain must be summarized to confront them to Corporate Law and Corporate Governance.

Basically, a Blockchain is a Public Register (1) that can both offer a way to exchange assets (2) and establish complex organizations and governance systems (3).

1. Public Register: by itself, the Blockchain is a Public Register. The Public feature of the Blockchain is required to achieve transparency. As there is no third party or central authority overseeing the system, the public itself must be able to access all the transactions occurring on a blockchain, either to use them (as nodes do) or to supervise them. Each Blockchain can therefore be downloaded by all users, containing all the past transactions since its creation. The Register can also allow access to more complex information such as music or pdf files, medical information ${ }^{12}$, etc. However, the fundamental feature of this function is the inalterability of the register, which participates in its security. In order to manipulate the register, it would be necessary to change all the past history of the register on a global scale: each and every version of the blockchain on all existing and active nodes would have to be similarly impaired. Such a manipulation would need an overwhelming computing power to "mine" new blocks in a more efficient and incentive way ${ }^{13}$. At last, the inalterability of the blockchain can allow the dissemination of authenticated information such a personal data or bank account information ${ }^{14}$.

2. Exchange Function: The second function of a Blockchain is to allow the exchange of assets. From a rather simple asset such as the Bitcoin to more developed one allowed by Ethereum, Blockchains allow a secured way to exchange resources. Blockchain allows also the use of tokens - called Ether for Ethereum - which represent a right to a given service or the use of a

hash with a Proof-of-Work system. The first node that manage to find a solution send it to all the other nodes. The new block is chained to the others and a new version of the blockchain is downloaded by all the other nodes. Tokens and transactions fees are transferred to the node who first found the solution as an incentive.

11 De Filippi P., Wright A., Blockchain and the Law: The Rule of Code, Harvard University Press, Cambridge Massachusetts, 2018, p. 13-32.

12 For instance MedRec: [https://ieeexplore.ieee.org/abstract/document/7573685/], accessed on $28 / 08 / 2018$.

13 Therefore, one who would possess such a computing power will earn more by using the power to the benefit of the system rather than to its detriment.

14 De Filippi P., Wright A., Blockchain and the Law: The Rule of Code, Harvard University Press, Cambridge Massachusetts, 2018, p. 18. 
prerogative such as a vote in a general meeting or the right to receive dividends. The exchange Function can be more sophisticated with the use of smart contracts, which allow automatization of exchanges. Using a single rule of "If... then...", a smart contract is a program functioning on the basis of Tokens. If a specific condition is fulfilled, the program will proceed by sending or blocking the use of an amount of Token or money. Such smart contracts can be linked together to build complex organization, where validation by the first is needed in order to use the second (and then third, and so on...). Such exchanges lower transaction costs as no intermediaries are needed, execution of contracts is instantaneous. Moreover, markets functioning on blockchain would access full efficiency as demonstrated by Fama ${ }^{15}$, given that certified information is accessible on real-time and without cost. As information and trading cost are equal to 0 on such a market, the price of the tokens will reflect perfect economical value of the underlying assets.

3. Organization and Consensus Facilitation: The global use of smart contracts leads to completely automatized and decentralized organization. The use of blockchain can facilitate the coordination of a social activity. A social institution is based on a collective idea put in motion by given governance and a decision system ${ }^{16}$. Some companies allow the automatization of governance systems such as the French Republic Constitution ${ }^{17}$. In theory, a business corporation could be organized solely on blockchain. The system would allow shareholders to register their titles in the blockchain and cast votes during purely virtual general meetings.

As previously described, a blockchain needs not a third-party to operate. Nonetheless, it is possible to restrain a blockchain by allowing a central authority to oversee it. Such a blockchain will lose its public and autonomous functions as the central authority will be able to supervise the transaction by itself, to unilaterally alter how the code functions and limit access to the blockchain ${ }^{18}$. Such "private" blockchain are referred under the term of "permissioned blockchain" $"$. Notwithstanding the loss of the philosophy behind the bitcoin in such a system, it remains a blockchain.

15 Fama E., Efficient Capital Market: A review of Theory and Empirical work, The Journal of Finance, 25(2), 1970, p. 383; Fama E., Efficient Capital Markets: II, The Journal of Finance, 46(5), 1991, [https://doi.org/10.1111/j.1540-6261.1991.tb04636.x], p. 1575.

16 To summarize the idea behind Maurice Hauriou institution: Millard E., Hauriou et la théorie de l'institution, Droit et société, 30-31, 1995, p. 381.

17 [http://klsn.io], accessed on 28/08/2018.

18 As it is the case for DTCC, for instance.

19 De Filippi P., Wright A., Blockchain and the Law: The Rule of Code, Harvard University Press, Cambridge Massachusetts, 2018, p. 31. 
What is the potential impact on corporate law and corporate governance? The rights traditionally granted to shareholders by law are principally exercised at the annual general meeting. These rights are twofold and comprise voting rights on one part, and financial rights on another. Closely connected to these two sets of rights, the information rights are also granted by law in order to make votes and financial rights more efficient, with legal intent prevailing over black-letter law. ${ }^{20}$ Beyond legal aspects, these rights are a strong element of corporate governance too, mainly the mainstream version of it, the 'shareholder primacy model'. ${ }^{21}$ This corporate governance model, focusing on the primacy of shareholders, seeks to maximize shareholder wealth and consequently avoid the existence of informational asymmetries between managers and shareholders. Emerging in the specific economic context of the 'modern corporation' fathered by Berle and $\mathrm{Means}^{22}$, it refers to large-scale manufacturing corporations in the wake of the second industrial revolution. It points out the lack of control on managers and potential conflicts of interests, occurring when managers act in their own self-interest -allocating high remuneration packages to themselves for example-, and extract benefits from the company. ${ }^{23}$ First developed in the United States, this theory later spread all over the world where a growing need for capital to build large infrastructure projects existed. ${ }^{24}$ Although this mainstream version of corporate governance model was challenged by other models ${ }^{25}$, pursuant to the Dodd doctrine ${ }^{26}$, it became the 'dominant ideology' ${ }^{27}$ in practice.

\footnotetext{
20 Germain, M. and V. Magnier, Ripert et Roblot, p. xxx.

21 Magnier V.: Comparative corporate governance. Legal Perspectives, Elgar ed., 2017, p.
} 15.

22 Berle A.A. and G. Means: The Modern corporation and Private Property, New York, Harcourt, revised ed. 1968.

23 Jensen M.C.; Mekcling, W.H., Theory of the firm: managerial behavior, agency costs and ownership structure, Journal of Financial Economics, 1976, 3, p. 305.

24 Dignam, A. and M. Galanis: The Globalization of Corporate Governance, Farnham, Ashgate Publishing, 2009; Gomez, P.-Y. and H. Korin: Entrepreneurs and Democracy: A Political Theory of Corporate Governance, London Business School, 2011.

25 Blair M.M; Stout, L.A: A team production theory of corporate law, Virginia Law Review, 1999, 2 (85), p.238; Blair, M.M: Shareholder value, corporate governance, and corporate performance: a post-Enron reassessment of the conventional wisdom, in Cornelius $\mathrm{P} ; \mathrm{K}$. Kogut B. eds: Corporate governance and capital flows in a global economy, Global outlook Book series, Oxford University press, 2003, p.53; Millon in Vasudev, P.M; Watson, S,: Corporate governance after the financial crisis, Edward Elgar, 2012.

26 Dood E., For whom are Corporate Managers Trustees?, Harvard Law Review, 45, 1932, p.1145.

27 Hansmann H. and R. Kraakman: The End of History for Corporate Law, Georgetown Law Journal, 89, 2001, p. 439. 
The right to vote and its corollary, the right to information, are a major concern to legal policy makers, be it hard of soft law. At the international level, the OECD Corporate governance Principles are a noticeable first attempt at establishing a universal set of principles for companies operating worldwide, with respect to sustainable economic growth. ${ }^{28}$ Whereas the OECD broadly defines corporate governance as 'a set of relationships between company's management, its board, its shareholder and its stakeholders', the principles focus on classical governance issues resulting from the separation of ownership and control. They mainly promote common rights and an equitable treatment for shareholders, with respect to shareholders access to information, to cross-border voting rights and the importance of fair and effective price discovery in stock markets. Following the same path, the EU institutions have issued the Shareholder Rights Directive 2007/36 ${ }^{29}$ revised in $2017 .{ }^{30}$ These texts have sought to facilitate the effective exercise of rights for shareholders in a globalized world. The revised 2007/36 Directive, amended by the xxx Directive, goes further so as to fill certain governance gaps in relation to the behavior of companies and their advisors, shareholders, proxies and proxy voting agencies. Member States have xxx years to implement the revised directive. France has done so with the Act $\mathrm{xxx}$ that will be discussed in the next sections of this paper. ${ }^{31}$

How BC may impact corporate law and corporate governance? Whereas this question is precisely the focus of this paper, it first advocates for a quick overview of the literature considering the general impact of blockchains on law and the various ways in which the two interact.

Blockhain technology is a typical record-keeping mechanism ${ }^{32}$ and as such may be considered as a ' $21^{\text {st }}$ century version of the recording systems that have been around since people started chiseling marks on cave walls'. ${ }^{33}$ In parallel, it is strongly argued that blockchains offer a revolutionary application of cryp-

28 OECD Principles of corporate governance, 2014 version, [www.oecd.org/corporate/2014-review-oecd-corporate-governance-principles.html.

29 2007/36 Directive, Magnier V., La démocratie actionnariale, D. 2007, p.x

30 2017/828 revised Directive on shareholders rights [https://eur-lex.europa.eu/legal-content/ EN/TXT/PDF/?uri=CELEX:32017L0828\&from=EN]

31 Barban P. : L'identification des actionnaires, Revue des sociétés, 12, 2017, p. 678; adde Germain M. et alii : Corporate governance in listed companies, Fondation nationale pour le droit continental, Semaine juridique, Entreprise et affaires ed,, 47, nov. 2013, 1639, p.22.

32 Among good other references, refer to chapter one entitled 'Blockchain technology basics' in Casey M. et alii eds : The Impact of Blockchain Technology on Finance: A Catalyst for change, Geneva Report on the World Economy, ICBM and CEPR, 21, 2018, p. xxx.

33 Cecchetti C et alii : Finance and blockchain, [online ref] accessed on 08/28/2018 
tography and information technology. ${ }^{34}$ The key question is the following: would this new technology impact law so as to transform law in such a way that it could be embedded in code? A big debate started on this subject a few years ago. On the one hand, most authors agree upon the absence of 'neutrality' of the blockchain technology. It is more generally the technological artifacts that are said to be not neutral. At least, two dimensions should be accoutered for justifying this non-neutrality. ${ }^{35}$ First, technology design is not neutral: ${ }^{36}$ whatever the presence of any intention behind a technological artifact, its design ends up imposing some types of actions or, on the opposite, preventing or even forbidding others. ${ }^{37}$ Second, they are politically-oriented. Put another way, the adoption of a specific technology, among others, reveals and influence the social and historical context in which this technology operates. ${ }^{38}$ Consequently, not only the choice of a blockchain regime would influence law, due to its particular design, but also the way it would be adopted would have great social and political (and legal) implications. In other words, like any other technological artifacts, blockchain is not neutral but 'inherently political'. ${ }^{39}$ On the other hand, authors go even further and have recently come up to argue that 'code is law'. This quote is referring to the idea that due to the highly performing codification process permitted by blockchains, code seems to be an extremely performing way to complete and even replace regulation. ${ }^{40}$ The last state of thoughts describes how law and code so interact that the blockchain is progressively meant to acquire 'the status of a regulatory technology', i.e. 'a technology that can be used both to define and incorporate legal provisions into code, and to enforce them. ${ }^{41}$ Ultimately, such a system would happen 'irrespectively of whether or not there subsists an underlying legal rule'. ${ }^{42}$ The authors do not say how this is feasible or desirable. ${ }^{43}$ Regardless of the fact that

34 Among good other references see De Filippi P. ; Hassan, S. : Blockchain technology as a Regulatory Technology : from code is law to law is code, unpublished paper [ssrn ref]

35 De Filippi P.; Hassan S. : see ref. note xxx

36 Winner, L.: Do artifacts have politics?, Daedelus, 1980, p. 121.

37 See examples in Smith, N.: The new urban frontier: gentrification and the revanchist city, Psychology press, 1996 ; Winner 1980 (see ref. note xxx).

38 Jeorges, B.: Do politics have artifacts?, Social studies of science, 29, 1999, p. 411.

39 Mowshowitz, A.: Computers and the myth of neutrality, Proceedings on the ACM $12^{\text {th }}$ annual computer science conference on SIGCSE symposium, 1984, p. 85.

40 De Filippi, P.; Hassan, S. (see ref. note $\mathrm{xxx}$ ).

41 De Filippi, P.; Hassan, S. (see ref. note $\mathrm{xxx}$ ).

42 De Filippi,P .; Hassan S. (see ref. note xxx).

43 For further discussion, see Yeung, K.: Regulation by Blockchain: The Emerging Battle for Supremacy between the Code of Law and Code as Law (July 2, 2018). Modern Law Review, Forthcoming. Available at SSRN: https://ssrn.com/abstract=3206546 
policy makers would not agree to abandon part of their authority to code, and judge would be still be needed to interpret general or ambiguous rules, costs of this process should be evaluate first. At least, costs of the proof of work needed to update the blockchain, like computer hardware and electricity, should be accounted for first. We doubt this could be achieved in a near future. Therefore, we adopt a more realistic and balanced view of the interaction between law and blockchains in the remainder of the paper.

Returning to the question at hand, in thinking about the challenge of impacting corporate law and corporate governance, it is useful to consider the different ways by which a blockchain regime might impair shareholders rights and managers behavior like they are currently defended by corporate law and developed by corporate governance recommendations.

The thesis defended in the article: on the one hand, we agree that BC technology is not neutral for corporate law and may have beneficial implications on corporate governance practice. On the other hand, we consider that 'Code is law' is not the right answer to BC technology regime adapted to corporate law and governance. This situation would be very risky on a legal perspective in the sense that it could challenge the very existence of underlying corporate law rules and impair good governance practice. This is not conceivable right now and we have little idea whether or when this would happen. Consequently, we defend a more balanced position: $\mathrm{BC}$ may favor a more democratic regime in a way that it may significantly facilitate procedural mechanism and, as such, upend the balance of power among managers and shareholders. These changes are to occur mainly in large corporations and may partly favor their best interest. However, we identify some risks that may be detrimental to shareholders' rights and impact the company as a whole. These risks seem significant as they are more qualitative than procedural: corporate governance practice could qualitatively suffer for BC, even though these risks are difficult to fully assess so far. The EU institutions have not taken these risks into consideration, despite they had the opportunity when revising the so-called Shareholders' Directive.

We argue that these novel risks associated with a BC technology use by large companies should be accoutered for by policy makers. The remainder of the essay is organized as follows: section 2 provides a description of the impacts of $\mathrm{BC}$ use by companies, questioning the potential emergence of a more direct shareholder democracy; section 3 presents the improved management tools; section 4 identifies potential risks associated with corporate governance of companies under $\mathrm{BC}$ regime; section 5 concludes the paper summing up arguments for coming up legal reforms at the EU level. ${ }^{44}$

44 NB: BC and company law and corporate governance might be studied in 2 aspects: (1) Governance under $\mathrm{BC}$ technology regime: how BC may affect Corporate law and corporate 


\section{THE POTENTIAL EMERGENCE OF A MORE DIRECT SHAREHOLDER DEMOCRACY?}

\subsection{OPEN ACCESS TO REAL-TIME INFORMATION}

The register function of a blockchain offers a way to facilitate the flow of information from the company and toward it. As recording simple to complex information is at the center of the blockchain, it offers a costless and efficient way to build a central database. The information stored in such a system will profit two kinds of data. First, the company-related information - which is often required by law and the focus of corporate governance - could be transmitted and stored into a blockchain (2.1.1.). Second, the organization of the shareholding structure could also profit the company itself, as it would be simpler for it to collect data about shareholders, hence improving knowledge of its capital structure and communication to the shareholders and stakeholders (2.1.2.).

\subsubsection{COMPANY RELATED INFORMATION}

Corporate law favors information rights toward shareholders, as premises toward the good use of their political and financial rights ${ }^{45}$. Moreover, principles of corporate governance advocate transparency toward shareholders in order to create a true shareholder democracy. This focus on information is patent under the Action plan for European company law and corporate governance: "Enhancing transparency - companies need to provide better information about their corporate governance to their investors and society at large. At the same time companies should be allowed to know who their shareholders are and institutional investors should be more transparent about their voting policies so that a more fruitful dialogue on corporate governance matters can take place." ${ }^{\prime 46}$ Some of the changes advocated have been settled as rules in the so-called directive for Shareholders" rights ${ }^{47}$. Legal requirement imposes

governance (i.e. can it upend the balance of power in companies?); (2) Governance of BC: Issues related to the internal governance of $\mathrm{BC}$, an important topic in the way that the organization of stock exchanges and other capital markets institutions is important today. This second series of issues will not be tackled with in the current presentation. Whereas the second point would be interesting to develop, the focus of this paper is on the first issue

45 See Supra.

46 Communication from the Commission to the European Parliament, Action Plan: European company law and corporate governance - a modern legal framework for more engaged shareholders and sustainable companies, (COM/2012/0740 final), 2012, 1. Introduction.

47 Directive 2007/36/EC of the European Parliament and of the Council of 11 July 2007 the exercise of certain rights of shareholders in listed companies (as amended by the directive 
the use of a central register, as in France the "Registre du commerce et des sociétés" in which key information about every company with legal capacity is accessible to the public (such as corporate name, business name, registered office, etc.). Major events in the life of a company are also registered, as change of representative in the company, opening of an insolvency procedure or its liquidation.

Moreover, it is the duty of the executive organ to report annually to the shareholders and establish the corporate accounts. In addition, auditors establish a special report in which corporate accounts and other sensitive information are certified. These duties are common to all companies, whether private or public.

Concerning public companies whose shares are negotiated on a regulated market registered in the EU, a set of European legal acts ${ }^{48}$ adds an additional layer of financial information. The United States also has such legal requirements under the Sarbanes-Oxley act of $2002^{49}$ and under S.E.C. Rules.

Firstly, information about the financial operation is due when a company asks for initial public offering and also seasoned public offering. The company will release a legal note including general overview of the company, accounting information and a description of the operation along with a resume.

Secondly, a public company must periodically release a report after each financial semester. Such a report, even if it shares some common features with the more classic annual report released by private companies, is often far more dense than the latter, as it contains more information related to the financial and non-financial affairs of the public company. It includes, for instance, all the corporate social responsibility information.

Lastly, a public company is obliged to immediately share to the public information that could impact the share price of the company, such as the withdrawal of an executive officer or an agreement with a major partner. Breach of such a duty can have major consequences as such undisclosed information

2017/828/EU of 17 May 2017 as regards the encouragement of long-term shareholder engagement), (OJEU 20/05/2017 L 132/1), (hereinafter, Shareholders' Rights Directive).

48 Directive 2014/57/EU of the European Parliament and of the Council of 16 April 2014 on criminal sanctions for market abuse (market abuse directive), (OJEU 16/04/2014 L 173/179), Directive 2017/1129 of the European Parliament and of the Council of 14 June on the prospectus to be published when securities are offered to the public or admitted to trading on a regulated market, (OJEU 30/06/2017, L 168/12), Directive 2014/65/EU of 15 May 2014 on markets in financial instrument, (OJEU 12/06/2014 L 173/349), Directive 2004/109/EC of 15 December 2004 on the harmonisation of transparency requirements in relation to information about issuers whose securities are admitted to trading on a regulated market, (OJEU 31/12/2004, L 390/38).

49 United States of America, The Sarbanes-Oxley Act, (Pub.L. 107-204, 116 Stat. 745). 
is qualified as insider information, which use on the market or simply transmission to a third-party is strictly forbidden and severely punished ${ }^{50}$.

This kind of duty is criticized as excessively costly for the companies. A special division must often be settled in such companies, labeled "Financial communication" with several employees affected to it. Moreover, it is often time consuming for the executive managers and directors ${ }^{51}$.

Could Blockchain help reduce the costs in terms of money and time of such information duties? The answer seems to be positive as the blockchain primarily works as a database register. It is no surprise then that the Delaware State now offers a Corporate Register built on that technology ${ }^{52}$. Blockchain can offer an alternative to the more ancient public registers and the most recent internet servers by offering a way to access immediately and cost-free as such information and to allow companies to provide this data under a rapid and automatized process. As long as complex information can be shared through the peer-topeer system, as it is the case $\mathrm{e}^{53}$, the nature of this information is irrelevant. It is therefore possible to share documents written in prose ${ }^{54}$ or numbers set into accounts $^{55}$, as it is already the case for the more classical Company Register. The quantity of information is also irrelevant once a system has been established. Private companies will have less information to transfer to the system, on the contrary of public companies which should also be more reactive to comply with the transmission of relevant information.

The advantages of such a system are clear. The information can be stored indefinitively and be time-stamped. Such information will be valuable in many fields only to verify that a company has correctly complied with its duty of information. In the case of insolvency law, such information is vital as it has a detrimental effect on the validity of some contracts and the rights to the creditors. For instance, in some countries, once an insolvency procedure is open, some contracts can be rendered void if they were concluded during a certain

50 Directive 2014/57/EU of the European Parliament and of the Council of 16 April 2014 on criminal sanctions for market abuse (market abuse directive), (OJEU 16/04/2014 L 173/179), Art. 3(2).

51 Engel E., Hayes R. M., Wang X.: The Sarbanes-Oxley Act and firms' going-private decisions, Journal of Accounting and Economics, 44 (1-2), 2007, [https://doi.org/10.1016/j.jacceco.2006.07.002], p. 116-145.

52 [http://fortune.com/2017/08/01/blockchain-shareholders-law], accessed on 28/08/2018.

53 V. Supra.

54 Such as the name of the company, the address of its registered office, the charts of association, activities reports to shareholders and so on.

55 All the corporate accounts. 
time gap before. It is the case especially for guarantee contracts. It is the same for the enforcement of contracts in France where creditors cannot ask anymore individually the enforcement of agreements. In that case, the time-stamp offers a perfect proof to settle disputes. We can also imagine, outside of corporate law, that if contracts are concluded in the form of a smart contract, the opening of an insolvency procedure will automatically void the smart contract or block its effects (in case of enforcement paralysis) without the need to ask that to a court.

What could be the architecture of such a system? Regarding public information, the system can be as basic as the bitcoin one. The data will be collected inside the system and made immediately public. Anyone logging on the system can access the information. The system will work based on mining by the companies themselves who will have to put some computing power in order to mine, mining allowing the right to send information to the blockchain. It is also possible, based on a token system, to allow auditors to access some private documentation in order for them to certify some data. The Blockchain could then offer File-Sharing services with restricted access to sensitive information $^{56}$. In order to certify accounts, auditors need to verify how evaluations were made and if the statements are accurate, faithful and provide a true and fair view of the company financial situation. The use of token will assure the confidentiality of such private documentation and the blockchain will then act as a virtual data room.

Such a system can be either public with no intermediaries or private. In a public system, no authority will check the quality of information sent to the system. Oversight would remain outside the blockchain where a judge or court clerk will continue to play that role. Some other drawbacks exist as it will be difficult to change or delete any information on that database, even if needed. Moreover, no control ex ante will be made as it is the case today in many system $^{57}$. In a private system, one intermediary will have the duty to verify ex-ante and be able to delete sensible information and correct mistakes ${ }^{58}$.

\subsubsection{SHAREHOLDING STRUCTURE RELATED INFORMATION}

Information is the key for a shareholder to use wisely and efficiently his shareholder's rights. It is necessary for him to receive information about the date of the annual general meeting, the place where it will be held, the proposed

56 De Filippi P., Wright A., Blockchain and the Law: The Rule of Code, Harvard University Press, Cambridge Massachusetts, 2018, p. 119.

57 Usually, Court clerks verify the data sent before publishing it to the central register.

58 See infra for more detailed drawbacks. 
resolution and all the relevant information (such as a resume of a proposed new executive manager or member of the board). This information is not made public before and therefore, does not belong to the former studied kind of information (even if, at the end, the record of the vote is made public).

To effectively receive this information, a shareholder must provide a way for the company to send it to him. Also, knowing the nature of its shareholder can help a company both to improve its corporate governance and to dialog more effectively with the blockholders and other influent shareholders ${ }^{59}$.

Nevertheless, the information that a company has over a shareholder is limited. It raises two intermingled questions. First, who is the effective shareholder in regard to corporate law; second, how to identify the effective shareholder?

The first question is vital as the effective exercise of the shareholders' rights only belongs to the person recognized by the local corporate law as shareholders. In small companies, such an issue does not exist: either the name and address of the shareholder is written in the article of associations (such as it is the case, in France, for the S.A.R.L.), either the title of the company is registered to a shareholder's account providing the name and address of that shareholder and managed by the company itself. Access and knowledge of this identity are obvious.

Usually, when the company becomes public, a more complex structure arises. Channels of intermediaries can be settled, where an intermediary will buy for the account of someone shares of the company. The latter can also be an intermediary who asked that on behalf of the final client who can also live outside the country where the company is registered. The titles are no longer nominal shares but bearers share, where the identity of the bearer can remain hidden. Also, in some systems, like the U.S., bank can buy large number of stocks and issue depositary receipts. They will be the main interlocutor with the issuer of the stock and receive the shareholders' information that they will transmit to the owners of the depositary receipts ${ }^{60}$.

Is such a system, a company needs to know who their shareholders effectively are. Several systems in the European Union instituted a procedure of shareholders' identification that could either rely on the intermediaries themselves or a central securities depositary (CSD). Usually, such a system must be settled by the law of the company. A company must then ask to all the intermedia-

\footnotetext{
59 On that subject: Becht M, Franks J., Mayer C., Rossi S.: Returns to Shareholder Activism: Evidence from a Clinical Study of the Hermes UK Focus Fund, Review of Financial Studies, 22(8), 2009, p. 3093-3129.

60 Bonneau T., Drummond F., Droit des marchés financiers, Economica Paris, 2010, p. 158.
} 
ries to transmit the information of their client in a bottom-up fashion. When the option exists, it can ask the CSD to provide a complete cartography of its shareholding structure. Such a procedure is time-consuming and the company itself supports the costs. The So-called directive about Shareholders right harmonizes the procedure of identification which will mainly be based on duties imposed on intermediaries. When a chain of intermediaries exists, those will have a duty to transmit the request to the known intermediaries without delay and responses must be transmitted directly to the company itself ${ }^{61}$.

Moreover, corporate law can also favor first layer owner of the share rather than the last layer. For instance, if an intermediary subscribed a share, on account of another intermediary on behalf of an investor, who will have the right to effectively cast the vote? Some systems, as France, favor the first layer as the owner of the share account is deemed to be the shareholder. Therefore, if such an intermediary casts a vote that does not comply with the instructions of its client, such a vote will be valid. Some countries, especially in Common Law systems, specifically make the choice to the final economic owner of the share that is the investor.

So, to summarize, there are two issues of corporate governance addressed here: information about shareholders and the effective use of shareholders' rights.

A blockchain system can solve both these issues. Such a system will be based on the identity of shareholders or intermediary and their inscription through a login. They can act either openly or pseudonymously in case of bearer shares ${ }^{62}$. In such a system, instead of shares being registered in a physical account held by the issuer or its intermediary, they will be created directly in the blockchain and then traded as any cryptocurrency. The main question is, however, the nature of such a share. Before the blockchain, shares could be traded on paper titles, the bearer of the paper being seen as the rightful owner of the share. They could also be held into the shareholder's account, which is the main system today in Europe. A central book is held by the issuer, and each issuance creates a given number of shares. For each shareholder, there will be a specific account created to register the number of shares he owns. Each one of those is the owner of an account with the number of shares he has purchased. For instance, if 1000 shares are issued, the issuer will mark this issuance in its book. It will then divide the 1000 shares between two subscribers: A would receive 400 shares and B 600 shares. Each investor will be the owner of own account.

\footnotetext{
${ }^{61}$ Shareholders' Rights Directive, Art. 3(a).

62 De Filippi P., Wright A., Blockchain and the Law: The Rule of Code, Harvard University Press, Cambridge Massachusetts, 2018, p. 38-39.
} 
In account $\mathrm{A}$ there will be 400 shares registered and in account $\mathrm{B}, 600$. If $\mathrm{B}$ sells 100 shares to $A$, then $B$ will ask the issuer to transfer 100 of his shares into account $\mathrm{A}$. The book administrated by the issuer is a way to recognize and enforce ownership upon the shares. This is the simplest stage, as the issuer can delegate the management of the accounts to a professional and a central securities depositary can centralize all the accounts of a large number of issuers.

The blockchain can be used in two ways. It can mirror the legal system of the shareholding with no binding effects. It would be necessary to translate the existing accounts into the blockchain to permit the flow of information. In such a system, if a shareholder sells his share, he must still give an order to the issuer or transmit the paper to the buyer. Then, someone has to register the transaction into the blockchain. Such a system is inefficient and there could be no synchronization at all between the real state of the capital and the one registered in a blockchain.

In is also possible to legally recognize a share registered on blockchain. In such a system, the issuance of shares would happen on the blockchain itself as well as the trading of the blockchain of shares. Such a system is more efficient hence some countries have adopted it, especially France, which allows the registering of shares either in a traditional account or on a blockchain ${ }^{63}$.

Anyway, any user of the system would have to identify either as the issuer (which will be unique for each share it issues), intermediary or investor. Each of these entities or people will be linked to a specific login effectively replacing the current share registers. Therefore, when an investor invests in a company through several intermediaries (the investor may not even know that a chain has been created), the system is able to share this information immediately to the issuer.

There will be no need any more to ask each intermediary the identity of the client on behalf of whom they act. Information could then be sent on a real time and cost free. Moreover, depending on the rule of the country in which the issuer is registered, the blockchain system could tag any link of that chain of intermediaries as the effective shareholder, allowing him to receive a token to exercise its voting rights. Intermediary links of the chain are usually not affected, as the logic is either to give such rights to the first layer or the last one. According to the lex fori, the system would automatically sent voting rights as token and relevant information to the effective shareholder.

63 France, Ordonnance $n^{\circ}$ 2017-1674 du 8 décembre 2017 relative à l'utilisation d'un dispositif d'enregistrement électronique partagé pour la représentation et la transmission de titres financiers, (JORF n ${ }^{\circ} 0287$ du 9 décembre 2017, texte $n^{\circ} 24$ ), art. 1 and curent art. L. 228-1 of the French Commercial Code. 


\subsection{VOTE AND SHAREHOLDERS' INVOLVEMENT}

In this part, we discuss how the use of BC technology by companies and for corporate governance may impact the vote itself (2.2.1), and behavior from activists (2.2.2).

\subsubsection{DIRECT VOTE}

Voting. Current limits to voting rights, largely fought by policy makers -be at the international, European or national levels-, and by investors are well known, and also regularly discussed among scholars. They are mainly obstacles of the concrete exercise of voting rights and comprise among others inexact voter lists, incomplete distribution of ballots, and even chaotic vote of tabulation. ${ }^{64}$ With the view to eliminate or at least alleviate these impediments to the correct exercise of voting, a few stock exchanges have experienced platforms for voting via blockchain technology ${ }^{65}$ Concretely, shareholders receive tokens, or so-called 'votecoins', that they can in return send to addresses on the $\mathrm{BC}$ in order to register their votes directly. ${ }^{66}$ According to authors promoting the use of $\mathrm{BC}$ for votes, the expected benefits are significant: among others, accuracy of BC voting and greater transparency ${ }^{67}$ would constitute a motivation for shareholders to participate more directly at the AGM. Hence, if used as a platform for voting, not only the $\mathrm{BC}$ would have effects on very practical issues in the exercise of the vote but would also significantly impact shareholders behavior. Consequently, it would permit a more direct shareholder democracy. Corporate governance issues, described in the Introduction part of this paper, would definitely benefit from the BC technology.

We fully agree that the exercise of the voting rights can benefit from the use of BC technology. First of all, the company would have a better knowledge of its shareholding, and this information would be available on real time. The list of voters should then gain in accuracy. The so-called 'record-date' mechanism, currently associated with the delays to register exchanges on a stock exchange, would be largely solved, letting this procedure aside and out of date. ${ }^{68}$

\footnotetext{
64 Kahan, M.; Rock, E.: The hanging chads of corporate voting, Georgetown law Journal, 2008, 96, p.1227; Germain M. et alii, see ref. note xxx ; Magnier V. see ref. note xxx.

65 In feb. 2016, the NASDAQ Talinn (Estonia) SE as a significant example.

66 Yermack, D. : 'Corporate governance and Blockchain', 2016, Working Paper No. w21802 NBER 16.

67 Wright, A.; De Filippi, P.: Decentralized Blockchain technology and the rise of Lex Cryptographia, 2015, unpublished paper, [ssrn.com/abstract=2580664]

68 Stock trades in US and several EU member states require 1 to 3 business days for settlement to occur and ownership to be transferred from seller to buyer. In the meantime, funds are
} 
Empty voting. A more crucial issue referred to as 'empty voting' consists in holding shares in a company while simultaneously selling them short. Consequently, an investor may use borrowed shares to temporarily cast a vote in a company without suffering from the economic exposure to the financial risks in the price of its stock. Separating the voting rights from the economic interest in the company represents a real threat to the basis of shareholder franchise ${ }^{69}$ Many policy makers including the European institutions have so far failed to regulate this technique. Using $\mathrm{BC}$ technology for share registration could limit this technique as it should provide more transparency and 'early warning of the rearrangement of voting rights prior to the AGM. ${ }^{70}$

Other obstacles related to 'cross-border' vote ${ }^{71}$ could be partly solved with the use of $\mathrm{BC}$ platforms for vote. Delegation to vote is a major issue. Economic surveys have shown that many elections in US companies ended up being decided in favor if management 'in a disproportionate' number of cases. ${ }^{72}$ Pressure or even manipulation on a dispersed and little involved ownership could be the cause. In European countries like France the same lack of engagement from several shareholders prevails, leading to the so-called 'blank check' practice: it is a default rule that permits shareholders to be represented at the AGM by the President of the meeting, but preventing them to give specific instructions in this case. This practice automatically and erroneously tends to favor management policies. ${ }^{73}$ The 2007/36 shareholder directive has failed to limit this practice. We suggest that any incentive to vote directly, including through a $\mathrm{BC}$ process, would hopefully favor direct voting and consequently diminish the influence from management on votes at the AGM.

The EU institutions particularly have to deal with the limited engagement of shareholders. Ironically, an additional issue related to delegation of votes came

exchanged between intermediaries and their clients, and shares are transferred on the books of the brokerage and the ledger of the company, under the supervision of the Clearing Central Depositary. Today, each settlement requires time and need numerous intermediaries. As rules fix the list of voters some (generally 3 ) days before the AGM is held, new shareholders are not registered for voting. Conversely, with a $\mathrm{BC}$ technology real-time information would permit to welcome new comers at the AGM.

$69 \mathrm{Hu}, \mathrm{H}$.; Black, B.: The new vote buying: Empty voting and hidden (morphable) ownership, Southern California Law Review, 2006, 79, p. 811. Adde Magnier V.: see ref. note xxx, p. 123.

70 D. Yermarck, see ref. note xxx.

71 For a thoughtful analysis of EU cross-border voting issues, see Noland, M. et alii: The political economy of cross-border voting in Europe, Columbia Journal of European law, 2009, 16 , p.1.

72 Listokin, Y.: Management always wins the close ones, American law and Economics Review, 2008, 10, p. 159.

73 ref. Comment VM directive 2007/36, supra note xxx. 
up as a side effect of the 2007/36 Shareholders' directive attempt to overcome the traditional rules set by Member States to limit delegations to vote. While the directive facilitated the exercise of voting rights opening this representation power to 'anyone' other the spouse or another shareholder, it gave way to representation by professional third-parties, the so-called 'proxy advisors'. Potential conflict of interests issues emerge when shareholders appealed to proxy advisors. It is worth confronting these issues with the $\mathrm{BC}$ use.

Proxy advisors. Proxy advisers are legal persons that analyses, on a professional and commercial basis, the corporate disclosure and, where relevant, other information of listed companies with a view to informing investors' voting decisions by providing research, advice or voting recommendations that relate to the exercise of voting rights ${ }^{74}$. They are key to the role of investment firms that own a large portfolio of shares and are unable to monitor the entire vote proposed at the AGM. The main purpose of proxy advisors is to analyze the resolution and give a recommendation to the voters. Often, the analysis is based on respect of corporate governance principles. They have major influence on certain votes such as remuneration of directors ${ }^{75}$ and they help shareholders to effectively exercise their voting right and avoid blank check practices. By registering their recommendation on a blockchain, proxy advisors could help shareholders to obtain in a quick and efficient way this recommendation and even to decide to follow them automatically. Moreover, as proxy advisors organize voting platforms for their clients, such voting platform could be established on a blockchain that could, in return, be linked to the blockchain where the shares of the company are registered ${ }^{76}$. It can also help for proxy solicitation in the country where it is useful, that is when it is easy to establish proxy voting ${ }^{77}$.

But such system is not neutral, as the proxy advisors can be subject to some conflict of interests as their profession is not neutral. For instance, they can both advise the company for establishing voting resolution and issue a recommendation. As blockchain facilitates the dissemination of the recommendation and the box ticking to fully vote following such recommendation, it can improve the detrimental effect of such conflicts ${ }^{78}$. Moreover, BC can facilitate a

\footnotetext{
74 Shareholders' Rights Directive, Art. 2(g).

75 ESMA 2012/212, Discussion Paper, 22 March 2012.

76 As for instance Broadbridge, a U.S. proxy advisor company: [https://www.globalcustodian. com/thought-leadership/future-proxy-voting/], accessed on 28/08/2018.

77 Such is the case in the U.S. where the proxy solicitation is oversight by the S.E.C. In France, it is much harder as it is limited to another shareholder, the spouse or the partner of a civil union when the company is private. Full liberty only exists in public companies: see art. L. 225-106 French Commercial Code.

78 The European Union has for regulated the proxy advisors through transparency: Shareholders' Rights Directive, Art. 3(j).
} 
proxy battle as the voting token could be easily transferred to such proxy advisors. As the issues linked to proxy fights are common knowledge, BC works similarly as a catalyst to them.

How assess the real impact of BC technology use for votes, so far? BC should definitely help moving towards a more direct democracy. At least, it could allow it. It remains to be seen if $\mathrm{BC}$ technology alone may restore and maintain confidence, one major corporate governance obstacle. ${ }^{79}$ We argue that this may happen only provided that company law and corporate governance improve to make sure trust and confidence be maintained:

First, BC will not, on its own, stop mechanisms like last-minute lobbying or 'behind the scene' discussions ${ }^{80}$ whose impact exceeds functional procedures. Corporate law and governance recommendations are still needed to restore the 'equal treatment of shareholders' ${ }^{81}$ Not all shareholders are involved in negotiations partially led between managers and some investors, prior or outside the AGM. Shareholders suffer from these arrangements as for company law principal of equality among shareholders. ${ }^{82}$ Conversely, BC use for votes does not preclude lack of engagement from small or minority shareholders when voting is at cost. In this respect, BC may be qualified 'neutral'. ${ }^{83}$ One major goal of the revised Shareholder directive in 2017 is to reinforce shareholders' engagement. A fair engagement still need to be encouraged by good governance practice like longer term perspectives and less selfish behavior from some investors. These obstacles to good governance practice are more qualitative than simply procedural. Finally, if BC technology could benefit to shareholder and help develop more democratic behaviors inside companies that have to $\mathrm{BC}$ platforms for voting, in a way that being addressed tokens directly on a BC allow votes to be quickly and securely recorded, it does not avoid a major risk, allowed by $\mathrm{BC}$ also, i.e. the lack of anonymity. ${ }^{84}$

\subsubsection{ACTIVISM-RELATED ISSUES}

If too little engagement from many shareholders is a corporate governance concern, activism from some others raises particular corporate governance issues. More specific to US/UK markets, activism is increasing in Europe due

\footnotetext{
79 See supra, introduction

80 'Behind the scene' see ref, Magnier, p. 131.

81 OECD Principles, see ref., note $\mathrm{xxx}$.

82 Magnier, V., supra note, p. 132.

83 See supra, 1

${ }^{84}$ See infra, 4.
} 
to active blockholders investing in European companies. ${ }^{85}$ Powerful professional shareholders, activists put pressure on boards to comply with their own strategy, mainly a short-terms-maximization-of-profit strategy that may be detrimental to longer-term expectations of the company itself. Despite the broadening consensus that engaging proactively in a company is vitally important, informal activism lowers the level playing field between shareholders. Among authors who predict greater transparency and improved liquidity on $\mathrm{BC}$, one assumes that the market could identify activists more easily, with a sort of chilling effect on activism, due to a more costly activism. ${ }^{86}$ This assertion is based on economic models showing that blockholders' trades are highly profitable during the period before they are required to disclose their ownership positions, but less once these positions are disclosed. ${ }^{87}$ This prediction favors the use of BC in company law. But, because these models are highly controversial, others coming up to the opposite conclusion, suggesting transparency helps major shareholders by improving liquidity and lowering their costs, ${ }^{88}$ we cannot further discuss this uncertain impact of $\mathrm{BC}$ use on corporate law.

More convincing is the 'Exit' threat argument defended by other scholars, ${ }^{89}$ because it works both ways. Depending on its real impact on the costs of selling, BC may modify the beneficial and strategic use of vote by activist shareholders. In the ever debated dilemma between 'voice' or 'exit', ${ }^{0}$ it is argued that activists' strategy changes according to the costs of selling: they choose to influence the company' managers though negotiation and participation when the costs of selling are high. Conversely, the lower the cost of selling, the more used the 'Exit' tool. Assuming with authors ${ }^{91}$ that a BC technology would significantly lower the costs of selling, we could anticipate that a $\mathrm{BC}$ frequent use by companies would have a great impact on their strategies: the 'Exit' threat could be reinforced and influence managers' strategic decisions so that

\footnotetext{
85 Magnier V.: see ref. note xxx, p.128.

86 Yermack, D. : see ref. note $\mathrm{xxx}$.

87 Kyle A.; Vila, J.-L, Noise trading and takeovers, RAND Journal of Economics,1991, 22, p. 54; Collin-Dufresne, P., Fos, V.: Insider trading, Stochastic liquidity and Equilibrium prices, Econometrica, 2016, 84, p. 1441; Collin-Dufresne, P.; Fos, V.: Do prices reveal the presence of informed trading?, Journal of finance, 2015, 70, p. 1555; Reported by Yermack, D.: see ref. note $\mathrm{xxx}$.
}

88 Reported by Yermack, D.: see ref. note xxx.

89 Reported by Yermack, D.: see ref. note xxx.

90 Voice or Exit ? ref

91 Edmans, A.: Blockholder trading, market efficiency, and managerial myopia, Journal of finance, 64, p. 2481; Admati A.; Pfleiderer, P.: The Wall Street walk and shareholder activism: Exit as a form of voice, Review of financial studies, 22, p. 2455: reported by Yermack, D., see ref. note $\mathrm{xxx}$. 
they satisfy investors' requests more rapidly. In the trade-off between shortterm - private benefits - versus long-term decisions - non-value maximizing projects -, the former would prevail on the latter. ${ }^{92}$ If the impact of $\mathrm{BC}$ could then be beneficial to major investors, it could possibly do so at the detriment of the company. Depending on how deal with the conflict of interests issue, BC use could bring new risks to companies. ${ }^{93}$

\section{IMPROVED MANAGEMENT TOOLS}

\subsection{A MORE EFFICIENT MANAGEMENT}

Business companies are complex organizations. They can be classified from the simple state of one representative with no board or oversight council to complex groups of multiple and large corporations.

The organization of power inside the company is the key to achieve corporate governance. The stakes differ according to the repartition of power inside the company. Usually, there is arbitration between power to the executive officers and power among the shareholders. This balance uses both prerogatives given to the different stakeholders and the use of sanctions by which the shareholders can revoke an executive officer, revoke the board, or ask for compensation in a tort-based claim.

There are roughly three levels to organize a company: the legal rule, the articles of association and shareholder's agreement.

The stakes also differ according to the social form of the company and the nature of the legal system. In France for instance, the law provides for the balance of power in the famous "société anonyme". On the opposite, the balance of powers is freely decided in the articles of association by the founders who choose to create a "société par actions simplifiée" 94 . The legal norm can be more or less restrictive or even completely silent.

Where the law is silent, the articles of the association set the main organizational rules of the company. This is the second level of organization and the founders, later the shareholders themselves, can set rules regarding proxy power in the company, attributions to the organs and duty from the executive officers toward the shareholders. The articles of the association can also rely on lower

92 Discuss here the potential impact of the Warren US project, the Accountable Capitalism Act.

93 See infra, part 4.

94 The law however asks for the institution of several organs and minimal attribution, such as the representative of the legal entity and the existence of an annual general meeting. 
norms such as bylaws adopted by the board, detailing some aspects of the rule. For instance, the articles can provide for the creation of a special committee and direct the board to establish its rules through the enactment of bylaws.

Lastly, some shareholders can decide to enter a covenant and sign a shareholder's agreement. Such agreements deal with the sale of shares in view to protect the consistency of shareholders' covenant or the use of voting rights (with some limitations such as the prohibition of voting rights sales). Agreements can be translated into the articles of association so as to facilitate their enforcement. They become then a full part of these articles applicable to all shareholders. They can, on the contrary, remain outside the scope of the articles of association and then act as regular contracts.

Blockchain can help with such organization on two levels: by setting a decentralized and autonomous organization based on a new blockchain system (3.1.1) or an existing one, such as etherneum or by the use of smart contracts (3.1.2.).

\subsubsection{DECENTRALIZED AUTONOMOUS ORGANIZATION (DAO)}

A DAO is a digital organization working on the base of a blockchain system. It can be built around its own system or instead use a pre-existing one. As authors stated, "Blockchains may serve as an interoperable layer for AI or algorithmic systems to interact and potentially even coordinate themselves with other code-based systems through a set of smart contracts acting as a decentralized autonomous organization"95. The purpose of such a DAO is to settle an autonomous organization where external intervention is not required. The operations are based on the use of the $\mathrm{BC}$ register, the implementation of autonomous smart contracts and the use of tokens. It can be used to implement a simple lottery system or be built on a more complex architecture. Resources needed for the use of the blockchain system (such as ether) can be provided by the members of the organization. Such token can be used to access resources provided by the DAO, such as dividends, or to represent rights upon the DAO, such as voting rights. For instance, a company offers to create complex organization based on Ethereum and offers a transcription of the French Constitution as a demo for its application ${ }^{96}$.

Once it is established, a company built around a DAO would need to function by authorization level. Each stakeholder must have a user login. Shareholders receive authorization to cast votes for AGM and the board members receive

95 De Filippi P., Wright A., Blockchain and the Law: The Rule of Code, Harvard University Press, Cambridge Massachusetts, 2018, p. 148.

96 See for instance [klsn.io] 
such an authorization for the matter relevant to their prerogatives. For instance, the distribution of dividends can be based on the net income in the database: shareholders cast a vote to decide whether to put it in a reserve account or to distribute them. If the latter is chosen, the DAO will automatically distribute dividends among the shareholders. Moreover, the use of a DAO could help render effective control upon remuneration instituted by the so-called shareholders' rights directive ${ }^{97}$ and that also exists in France ${ }^{98}$. A company can or must make mandatory a previous agreement of the AGM prior to the payment of directors. Smart contracts can then retain that payment if the vote is negative. Related to remuneration, a DAO can also effectively manage the distribution and exercise of stock options. A director could receive his stock options when the financial results are obtained. When a golden parachute has been voted, distribution can be made upon revocation... As the code is public, it is also a better way for shareholders to manage more efficiently the global remuneration of directors and board members.

The shareholders' rights directive entitles the board to authorize some contracts between the company and related parties, as it is the case when a board member signs an agreement with the company itself. Such a procedure could be automatized ${ }^{99}$.

More complex interactions can also be settled. Suppose that the election of a new board member is proposed to the AGM. If the candidate has a user login, a positive vote would have for effect to give him access to information stored on a blockchain and to receive a token for any vote inside the board.

As we can see, a company can be organized through a DAO but it needs the correct coding to achieve automatization. If the basic activities can be so coded, some activities cannot and there will always be the need to rely on human input inside the system itself. Some parts of the organization cannot be coded also, especially when the power given to the shareholders or the directors is too general and too vague. Where there is a fiduciary duty ${ }^{100}$, it will be in fact impossible to translate such a duty into a $\mathrm{DAO}^{101}$. The breach of such a duty

\footnotetext{
97 Shareholders' Rights Directive, Art. 9(a).

98 France, Loi n 2016-1691 du 9 décembre 2016 relative à la transparence, à la lutte contre la corruption et à la modernisation de la vie économique, (JORF nº287 du 10 décembre 2016, texte $\mathrm{n}^{\circ} 2$ ), art. 161 .

99 Shareholders' Rights Directive, Art. 9(c).

100 As it is the case in France, see Germain M., Magnier V., Les sociétés commerciales, L.G.D.J. Paris, 2017, $\mathrm{n}^{\circ} 1671$.

101 It would be the same in the very frequent non-disclosure agreement, where the breach is impossible to code correctly.
} 
will need court recognition. Moreover, if damages are requested, it will require an appreciation of the court if no penal clause was instituted. Other fields are subject to such uncertainty. For instance, the directive on shareholders' rights states that "Member States should ensure that material related party transactions are submitted to approval by the shareholders or by the administrative or supervisory body according to procedures that prevent the related party from taking advantage of its position and provide adequate protection for the interests of the company and of the shareholders who are not a related party, including minority shareholders." 102 Yet, the definition of a related party remains blurred. If the related party is directly a shareholder or a director, there are a few issues as those are registered on the blockchain. A simple system of recording some contracts into the system could help to initiate a procedure. But if the related party is not registered or is a hidden agent of the formers, then there is no way to allow the blockchain to cover such an event.

Therefore, most of the time, the DAO will be a hybrid contractual organization $^{103}$. The articles of association will then be settled on prose as a master agreement, while all the simple and technical clauses will be settled on the blockchain. The master agreement, for some clauses, will then rely on the block chain and for other on the prose, when they are more open-ended.

Despite these limitations, the major decisions held by the AGM such as nominations/remuneration of directors, approving of financial statements and dividends can easily be coded. Those offers the shareholders access to instantaneous use of their rights and protect them from fraud or dilatory actions from the executive board or representatives of the company.

\subsubsection{SMART CONTRACTS}

When a shareholders' agreement is not enacted on the articles of association, it remains a contract ranging from simple ("if you sell your shares, you must buy mine at the same price") to very complex. But a contract written in prose can contain clauses far vaguer than contract translated in a program. The program can only function precisely if no human interaction is needed. The prose contract can contain definition clauses, a setting of goals but also general notions that can more easily embrace the totality of the hypothesis the contract tries to rule. On the opposite, smart contracts work solely on the basis of an "if...

102 Directive 2017/828/EU of 17 May 2017 as regards the encouragement of long-term shareholder engagement, (OJEU 20/05/2017, L 132/1), whereas 42.

103 De Filippi P., Wright A., Blockchain and the Law: The Rule of Code, Harvard University Press, Cambridge Massachusetts, 2018, p. 76. 
then..." rule. If conditions are vaguer and more human decision needed, then a human input is required, thus voiding the automatic aspect of smart contracts. However, it can prove impossible for some clauses to be translated, as vague terms or unknown conditions are prerequisites. It can prove useful for contractors to use general notions as "good faith" since several legal systems rely on this. Those broad notions help to cover the wide range of behaviors contractors could have or events they could face. Also, some goal can be set in a contract, usually at the beginning of it, to help to determine the correct behavior. Without these clauses, the future cannot be usefully managed and predicted. Yet, it is the main purpose of a contract. It simply means that some agreement will rely on human interaction, from the contractors themselves, an independent expert or a court decision. Therefore, some contracts will need to be hybrid contracts, as seen hereinbefore.

Aside this obstacle and postponing for now the risk aspects ${ }^{104}$, such an organization of a shareholders' agreement offers two main advantages ${ }^{105}$.

First, the monitoring costs decrease even to 0 , as a smart contract automatically reacts if it gets the right inputs. It proves very useful especially for the two main clauses existing, the voting clauses and the shares selling clauses. If a voting clause is set, then the smart contract will automatically adjust the voting token of the debtors to the one of the creditors. If the creditors use their token to vote positively, the smart contract will use the token of the debtors to vote alongside. Similarly, the selling of the shares of the debtor of the clause to a buyer will cause the automatic selling of the creditor (who could get an option as a phone notification for instance, to react instantaneously). Therefore, the parties to the agreement won't need to oversee the contract but instead just let the smart contract work by itself.

Second, the smart contract will diminish the opportunistic behavior of the parties. On the one hand, the use of vague clause that can lead to discussions in court, and therefore delay the enforcement of the agreement, will be nullified. The program will need to put precise mechanisms that do not allow human interpretation. On the other hand, the contract based on a blockchain is protected against the risk of fraud, as long as one of the parties cannot own more than $50 \%$ of the mining power of the blockchain.

\footnotetext{
104 See infra.

105 De Filippi P., Wright A., Blockchain and the Law: The Rule of Code, Harvard University Press, Cambridge Massachusetts, 2018, p. 80.
} 


\subsubsection{BC LEGAL EXPERT}

The use of BC to organize a company could foster the rise of a new kind of employee, officer or director (even on board), or even a whole new service inside the company to help organize a blockchain-structured company. Such a field of expertise will require skills embracing both the IT field and the legal field, in order to transpose correctly an organization into a blockchain. Given the key role such an actor could have, and keeping in mind the incorruptible aspect of the blockchain once it is established, her or his role will be sensible during the transposition phase, when a new set of rules must be translated into computing language. Contractor managers, given they acquire the needed skills in computing, could prove valuable.

As such a service will have to manage sensible aspects to correctly translate legal or contractual terms in a smart contract and a DAO, some regulation would be needed. They will in fact act as internal controllers and other compliance officers, but not regarding activities of the firm rather its structure at its heart. The risk of capture by the management is high, especially if such an expert is an employee of the firm. Therefore, they would need to be neutral, have direct access to the core management but also be able to warn the shareholders in case of a major breach in the organization. They should at least benefit from the protection compliance officers have and, at the most, be totally independent, such as auditors are. The auditors could also embrace such an activity if the correct Chinese wall or incompatibilities are maintained, so that a unique auditors firm audits both accounting and the blockchain aspect.

\subsection{RELATED-PARTY TRANSACTIONS ISSUES?}

Related-party transactions are a major corporate law tool used to protect the company against conflicts of interests. Regulated in almost every jurisdiction it is based on a two-phase mechanism: traditional ex-post enforcement and an interesting ex-ante declaration process. The latter applies by prevention to agreements between the company and its managers or referential shareholders. Information is given to the board by the 'interested' person (in situation of potential conflict of interests). The board, with the exception of this director, authorizes (or not) the agreement and, later, this authorization is approved (or rejected) by shareholders (except the 'interested person') at the AGM. Damaging override of the rejection may lead to sanctions to the interested person. The preventive disclosure rules place a burden upon management to self-report these transactions and compliance may be subject to misinterpretation and uncertainties, when it is not respected at all. The revised Shareholders' directive has attempted to deal with issues related to third-party transactions (à comple- 
ter). But more improvement is needed. As preventing people from breaching the rules should prevail on sanction, $\mathrm{BC}$ may help improving the rules in two ways. First, greater transparency offered by BC technologies would permit to engage in real-time control against fraudulent agreements. Damages to the company could hence be more easily avoided. Second, one could imagine an automatization of standardized and sequential agreements. This automatized process currently exists through a smart contract. Smart contracts are small snippets of code that are directly deployed on the BC and meant to be executed in a decentralized manner in the BC network. ${ }^{106}$ As computer programs, they are neither smart (they still need a human intervention to be put it in place) nor real contracts (they only can represent copies of agreements or facts, or images etc...). Yet, these programs may help to emulate the correct execution of real agreements. If we follow Szabo, and De Filippi and Hassan ${ }^{107}$ - with no need here to discuss the feasibility of transposing every single legal rule and document into code -, smart contract 'are able to automatically execute the terms of a specific agreement, providing trustless transactions via integrated enforcement mechanisms', we suggest that such a tool be useful to automatize at least a great deal of (if not all) related-party agreements in groups of companies. Not only these agreements are frequent, but most of them are also standardized and sequential. In such a case, BC technology would hence help improving and securing the ex-ante phase of the rules related to these agreements, consequently improving management tools.

\subsection{GREATER TRANSPARENCY OF INSIDER TRADING OPERATIONS?}

Again, if BC technology offers greater transparency, it would be interesting to question the impact of its use on insider trading. Insider trading is illegal in US and Europe, criminal related sanctions being recently reinforced in the European Union via the 596/2014 Rule and other texts. ${ }^{108}$ Insider trading regulations constrain directors and managers from selling or buying shares of the company they manage benefiting from significant information prior to make it public to the market. Greater transparency on (public) BC would permit boards or shareholders observe managers' trades in real time, offering an accurate on-time control on these illegal behavior. ${ }^{109}$

106 For more details on smart contracts, see Szabo, N.: Smart contracts, 1994, unpublished paper [http://Szabo.best.vwh.net/smart.contracts.html].

107 De Filippi, P. ; Hassan, S. : see ref. note xxx

108 EU insider trading rule [online ref]

109 Discuss the benefit from legal or illegal insider trading as a compensation tool 


\section{THE POTENTIAL ALTERATION OF SOME CORPORATE GOVERNANCE ARRANGEMENTS: EMERGENCE OF NEW GOVERNANCE RISKS}

The use of blockchain is not without risks. They can even void some security offered by the legal system itself, as they require renouncement of anonymity (which is sometimes the key). Three key features of a blockchain system can create new governance risks. Firstly, the transparency on a blockchain can prove adverse to governance and some management's decisions will lack the required confidentiality (4.1.). Second, the permanent structure of a blockchain can prove detrimental when a human intervention is needed, such as a court decision (4.2.). Moreover, errors in the blockchain can prove difficult to adjust, with the potential of global paralysis of the company (4.3). Finally, conflict of interest may remain or be worsened on a blockchain as it is code and algorithm based (4.4.).

\subsection{LACK OF CONFIDENTIALITY UNDER A BC REGIME}

A public blockchain is necessarily transparent. This feature is the key to the rise of a trustful system with no third-party. However, if transparency is required $^{110}$, some privacy may be maintained as clearly stated in Nakamoto original white Paper: "The necessity to announce all transactions publicly precludes this method, but privacy can still be maintained by breaking the flow of information in another place: by keeping public keys anonymous." 111 Nonetheless, it may prove hard to keep key information private in such a system, both in the detriment of the shareholders (4.1.1.) and the company itself (4.1.2.).

\subsection{1. 'OPEN' VOTES; DISTINGUISH THE IMPACT ON PRIVATE/ PUBLIC BC}

When the shares of a company are registered on a blockchain, each shareholder will have to register itself on that blockchain ${ }^{112}$. The use of anonymity is, however, limited to the general public. As the original white paper states, "The public can see that someone is sending an amount to someone else, but without information linking the transaction to anyone. This is similar to the level of

110 De Filippi P., Wright A., Blockchain and the Law: The Rule of Code, Harvard University Press, Cambridge Massachusetts, 2018, p. 37.

111 [https://bitcoin.org/bitcoin.pdf], accessed on 28/08/2018, esp. "10. Privacy".

112 See supra. 
information released by stock exchanges, where the time and size of individual trades, the "tape", is made public, but without telling who the parties were."113 However, such an "anonymity" 114 has its limits. To enforce the shareholders right, the shareholder must have its identity disclosed at one point of the system, at least to assume its ownership of the shares. The actual system of intermediaries would remain: if a shareholder can add many layers between him and the issuer, which usually protects anonymity, the blockchain system can track him instantaneously by a simple bottom-up check. Same if the true shareholder tries to add its identity under several financial vehicles. If all of them are registered on a blockchain, such effort will be fruitless. Only if, at one point, the chain exits the blockchain system, such stratagem would work. To protect himself, the shareholder will have to use a hidden agent or a front man, at the risk of not being able to enforce his shareholder rights. An intermediary has the duty to comply with the orders of his client, contrary to a shadow agent working outside the legal system.

Is that to say that the rise of shares registered blockchain will destroy anonymity? At some point yes and we can conclude at the end of anonymity of the bearer-shares. But that kind of issue is not so detrimental, as the legal system evolves in a way to hamper this transparency nonetheless. The recent amendment of the shareholder rights directive states the possibility for all public companies relying on this bearer shares to identify their shareholders ${ }^{115}$. All the bearer shares under such a system will become identifiable, unless the member state uses the option to protect the shareholders detaining less than $0.5 \%$ of the shares, in other words, the powerless ones inside a company. Blockchain will not protect shareholders from that identification and can also facilitate that process ${ }^{116}$.

\subsection{2. 'OPEN' ACCESS TO TRANSACTIONS}

Usually, company directors cannot hold bearer shares rather nominal shares. Such a legal provision seeks to oversee insider trading. However, unlike in a traditional system where the public cannot clearly see management transa-

\footnotetext{
113 Ibid.

114 "There are no real-world identities required to participate in the Bitcoin protocol. Any user can create a pseudonymous key pair at any moment, any number of them", in Narayanan A. e.a., Bitcoin and cryptocurrencies technology, Princeton University Press, 2016, De Filippi P., Wright A., Blockchain and the Law: The Rule of Code, Harvard University Press, Cambridge Massachusetts, 2018, p. 38, ad notam 10.

115 See supra.

116 Supra.
} 
ction, the public aspect of a blockchain allows it. Investors and other third parties to a company could receive real-time feeds on the activity of the top management, thus misinterpreting shares selling or buying. It could impact the share price dramatically and create unexpected volatility on capitalization, detrimental to the true company value.

\subsection{WHAT IF A NEED TO APPEAL TO A NEW THIRD PARTY OCCURS?}

It is sometimes deemed necessary for a third party to intervene in the affairs of the company, for instance between shareholders tied by a shareholding. When a shareholder agreement agree to the future selling of shares, as an option for one party or due to a certain event, price of the shares cannot always be based on objective data. It is particularly true when the company is private as there is no capitalization value. It is also true of some agreements in public company, when the selling implies transfer of control, as a premium must then be paid. Therefore, an expert must intervene.

Moreover, it is sometime necessary for a judge to intervene in the functioning of a company when the company itself may face paralysis. It can be for very basic reason as an organ cannot work normally after certain events. For instance, if all the member of the board were to die in a plane crash, a new board would have to be named. Usually, board members are nominated by an AGE. But it is the board itself that must summon such an AGE, which is impossible if there are no more board members... In that case, France has a judiciary system where the court will name a special representative whose mission is to summon the board and take the decision to summon the AGE, such resolving the issue of paralysis. A wide array of case relies on such a human intervene. For instance, if a manager act in a way that harm the interest of the company and its shareholders, but that manager has control over the company, corporate rules cannot allow his revocation. It is then necessary for a judge to intervene and if the activity of that manager is harmful to the company, to demote him.

Finally, many insolvency procedure works in a way where the court demote directors from their position to name a special agent acting as the proxy of the company.

All this human intervention cannot be translated into code. Moreover, for some of them, the human intervention is taken as the consequences of a dispute between shareholders and managers, so the managers who owns the access to take certain decision can refuse such access which will later need prosecution. Until then, paralysis may remain or certain harmful actions can be taken. The only possibility would be to organize the whole judiciary and expertise system into a blockchain, which is utopic, unfeasible and undesirable. 


\subsection{WHAT IF BC ERRORS OCCUR, FOLLOWED BY INERTIA?}

Blockchain is a large decentralized ledger registering all information data made since the beginning. Data stored in a BC cannot be retroactively modified or deleted. Immutable preservation and traceability of operations are therefore two major assets of a BC. However, no technique is $100 \%$ reliable. Cryptocurrencies, Ethereum ${ }^{117}$ or Bitcoins, can be diverted thanks to a computer fault. The private key may be hacked even though this risk should not be overstated. ${ }^{118}$ It is minimal when the company is a knowledgeable professional who will not leave his private key accessible on the web. Another risk could come up from a possible collusion of miners gathered in 'pool' who divert the information. ${ }^{119}$ This happened in countries where electricity is cheap (China) or easy cooling (Iceland), in order to pool the computing power of different computers. ${ }^{120}$

On a public $\mathrm{BC}$, the state of the $\mathrm{BC}$ can only be updated through consensus so that is unfalsifiable (consensus technique). It is almost impossible to change the contents of a $\mathrm{BC}^{121}$ because more than $51 \%$ of the computing power of all computers participating in the mining is needed to do so. However, a real governance problem in public $\mathrm{BC}$ exists because no authority is designed to resolve the difficulties or any key revocation system. This situation raises the issues of liability. Who would then be liable when data are modified or fake information is spread through a BC ledger? The developer who set up the BC - with a protocol of operation - and raised funds to pay minors in cryptocurrencies? Or the start-up of $\mathrm{BC}$, the chaintech, who is an intermediary to the company that uses a $\mathrm{BC}$ platform, in particular to register its bylaws, AGM or financial reports, and contractual agreements? Because of the decentralized organization of the $\mathrm{BC}$, neither the developers nor the chaintech can have control on a public BC. Only the communities of miners, developers and users have the power to modify the initial protocol on a decentralized organization with no centralized control.

\footnotetext{
117 A failure in the code of a smartcontract has been exploited on Ethereum BC.Consequently, the consensus was to split the BC ('fork) and initial funders were reimbursed.

118 On Bitcoin or Ethereum BC, non-professionnals had left their cryptomonney on public addresses and the platform held the private key.

119 To avoid risks of collusion, other mechanisms have been studied like the proof-of-work scheme. It requires that a potential thief or forger have to alter not only the transaction record they wish to divert, but also all subsequent blocks up to the current one. According to this scheme, altering historical data in a $\mathrm{BC}$ prohibitively costly.

120 D.Legeais, Juris-classeur Comm.Fasc. 534.

121 Since the hash of the block header is included as an element in the header of the next block, the hash of the next block header will also change, as will the subsequent block headers.
} 
The risk of hacking is even greater in a private $\mathrm{BC}$ managed by an administrator, because a hacker can infiltrate the network of this administrator. In addition, in a private $\mathrm{BC}$, the network administrator can modify the operating rules of the $\mathrm{BC}$ as well as the content of the $\mathrm{BC}$. The value of the evidence in a private $\mathrm{BC}$ cannot be the same as in a public $\mathrm{BC}$.

Failures in the BC technology already happened. These failures may undermine confidence in this new technology. These technological issues should be fixed prior to be used at large scale by companies.

\subsection{POTENTIAL CONFLICT OF INTERESTS ISSUES}

Conflicts of interests are a major issue in corporate law and governance. Jensen and Meckling, who defended the agency theory, conflicts of interests between managers, as agents, and shareholders, as principals, occur when the former act in their own self- interests, by extracting benefits from the company, all at the detriment of the shareholders' and the company's interests. Such opportunistic behavior results in agency costs, including losses in corporate value, permitted by informational asymmetries at the benefit of managers. The key governance solution to avoid discretionary opportunistic behaviors and make managers behave fairly is brought through greater transparency. Such mechanisms as 'say on pay'122 or "related-party transactions' ${ }^{123}$ are part of the solution. As shown above, these mechanisms are easy to code as long as their substantial clauses remain quantitative (amount of remuneration or deal). When the clause need be more qualitative, like codifying a 'good faith' situation, code seems of no real help. On BC, greater transparency should therefor prevail, ${ }^{124}$ helping limiting conflict of interests. But this is mainly true for forms of 'quantitative' situation. As for more 'qualitative' ones, classical human resources and controls should still be relevant. If not clearly identified, and solve, these differences may impair the companies' activities, trust on the markets and altogether the use of $\mathrm{BC}$ as a benefit for corporate governance.

\section{CONCLUSION}

Our finding is that considering that the main issues with the use of a Blockchain is its transparent and permanent setting, this kind of features comply hardly with the needs of business activity and companies. Therefore, before setting a

122 See supra.

123 See supra.

124 See supra. 
blockchain, one must remain conscious of the way he wants to settle it. It can either be public or private. When a register is established on blockchain, the use of a third-party can prove vital.

The governance of such a record will either been made through a central authority or will rely on public transparency and no third-party. A purely decentralized record would cost obviously less as there will be no intermediation cost for the authority overseeing the blockchain. However, such a system could be sensible to fraud and overtaking. If someone manages to obtain more than $50 \%$ of the miners computing power, it will be able to alter the blockchain and render void the authenticity of the data stored in $i^{125}$. He would be able to add false information or delete previous information. Trust in the register would then be nullified. Moreover, in such a system, there would be no quality control other than the public. It is unsure that vigilant public overseeing regarding all the companies will work. The amount of work would be enormous when the gains are weak. Moreover, if false information is stored, it is extremely difficult to correct it on a public blockchain. On the contrary, a private blockchain relies on a central authority which oversees the faithfulness of the data and corrects the database if an error occurred ${ }^{126}$.

More importantly, a public blockchain will not permit any right to oblivion for former executive officers whose name is bound to the insolvency of their former company. Such right to oblivion can exist in some exceptional cases ${ }^{127}$. Such issues can be addressed with a third-party but can hamper the key features of a blockchain. Arbitrages must be made by legislator.

Finally, no doubt BC technology is not neutral for corporate law. Corporate governance could change in some ways under a $\mathrm{BC}$ regime and the balance of power may significantly be upended among actors, i.e. small/large shareholders and managers. Corporate governance may also benefit from it on democratic grounds. However, legal and financial risks may occur for the company and its shareholders. These opportunities and risks should be taken care of. Policy makers should be aware of both of them and bring adapted answers to the issues related to the new technology.

Considering the limits of the article, here are additional thoughts for further potential discussion. Mainly three questions need to be raised and solved: (1) What type of reform: max/minimum changes?; (2) Which level? In Europe:

125 De Filippi P., Wright A., Blockchain and the Law: The Rule of Code, Harvard University Press, Cambridge Massachusetts, 2018, p. 113

126 De Filippi P., Wright A., Blockchain and the Law: The Rule of Code, Harvard University Press, Cambridge Massachusetts, 2018, p. 114.

127 EUJC, 9 march 2017, aff. C-398/15, Camera di Commercio c/ Salvatore Manni. 
Member states reform or EU Directive? (3) Governance OF BC themselves (see introduction).

\section{LITERATURE}

1. Admati A.; Pfleiderer, P.: The Wall Street walk and shareholder activism: Exit as a form of voice, Review of finance 22, p. 2455

2. Barban P. : L’identification des actionnaires, Revue des sociétés, 12, 2017, p. 678

3. Berle A.A. and G. Means: The Modern corporation and Private Property, New York, Harcourt revised ed. 1968

4. Becht M, Franks J., Mayer C., Rossi S.: Returns to Shareholder Activism: Evidence from a Clinical Study of the Hermes UK Focus Fund, Review of Financial Studies, 22(8), 2009, pp. 3093-3129.

- DOI: https://doi.org/10.1093/rfs/hhn054

5. Blair, M.M: Shareholder value, corporate governance, and corporate performance: a post-Enron reassessment of the conventional wisdom, in Cornelius $\mathrm{P}$; K. Kogut B. eds: Corporate governance and capital flows in a global economy, Global outlook Book series, Oxford University press, 2003, p.53

- DOI: https://doi.org/10.2307/1073662

6. Blair M.M; Stout, L.A: A team production theory of corporate law, Virginia Law Review, 1999, 2 (85), p.238

7. Bonneau T., Drummond F., Droit des marchés financiers, Economica Paris, 2010

8. Casey M. et alii eds : The Impact of Blockchain Technology on Finance: A Catalyst for change, Geneva Report on the World Economy, ICBM and CEPR, 21, 2018

9. Cecchetti C et alii : Finance and blockchain, [online ref] accessed on 08/28/2018

10. Collin-Dufresne, P.; Fos, V.: Do prices reveal the presence of informed trading?, Journal of finance, 2015, 70, p. 1555

- DOI: https://doi.org/10.1111/jofi.12260

11. Collin-Dufresne, P., Fos, V.: Insider trading, Stochastic liquidity and Equilibrium prices, Econometrica, 2016, 84, p. 1441

- DOI: https://doi.org/10.3982/ECTA10789

12. De Filippi P., Wright A., Blockchain and the Law: The Rule of Code, Harvard University Press, Cambridge Massachusetts, 2018

- DOI: https://doi.org/10.2307/j.ctv2867sp

13. De Filippi P. ; Hassan, S. : Blockchain technology as a Regulatory Technology : from code is law to law is code, [https://papers.ssrn.com/sol3/papers.cfm?abstract_id=3097430] 
14. Dignam, A. and M. Galanis: The Globalization of Corporate Governance, Farnham, Ashgate Publishing, 2009

15. Dood E., For whom are Corporate Managers Trustees?, Harvard Law Review, 45, 1932, p.1145

- DOI: https://doi.org/10.2307/1331697

16. Edmans, A.: Blockholder trading, market efficiency, and managerial myopia, Journal of finance, 64, p. 2481

- DOI: https://doi.org/10.1111/j.1540-6261.2009.01508.x

17. Engel E., Hayes R. M., Wang X.: The Sarbanes-Oxley Act and firms' going-private decisions, Journal of Accounting and Economics, 44 (1-2), 2007, p. 116-145

- DOI: https://doi.org/10.1016/j.jacceco.2006.07.002

18. Fama E., Efficient Capital Market: A review of Theory and Empirical work, The Journal of Finance, 25(2), 1970, p. 383; Fama E., Efficient Capital Markets: II, The Journal of Finance, 46(5), 1991

- DOI: https://doi.org/10.1111/j.1540-6261.1991.tb04636.x

19. Germain, M. and V. Magnier, Ripert et Roblot, Société commerciales, LGDJ ed. 22, Paris, 2017

20. Germain M. et alii : Corporate governance in listed companies, Fondation nationale pour le droit continental, Semaine juridique, Entreprise et affaires ed, 47, nov. 2013, 1639, p.22

21. Gomez, P.-Y.; H. Korin: Entrepreneurs and Democracy: A Political Theory of Corporate Governance, London Business School, 2011

22. Hansmann H. and R. Kraakman: The End of History for Corporate Law, Georgetown Law Journal, 89, 2001, p. 439

23. Hu, H.; Black, B.: The new vote buying: Empty voting and hidden (morphable) ownership, Southern California Law Review, 2006, 79, p. 811

24. Jensen M.C.; Mekcling, W.H., Theory of the firm: managerial behavior, agency costs and ownership structure, Journal of Financial Economics, 1976, 3, p. 305

- DOI: https://doi.org/10.1016/0304-405X(76)90026-X

25. Jeorges, B.: Do politics have artifacts?, Social studies of science, 29, 1999, p. 411 - DOI: https://doi.org/10.1177/030631299029003004

26. Kahan, M.; Rock, E.: The hanging chads of corporate voting, Georgetown law Journal, 2008, 96, p.1227

27. Kyle A.; Vila, J.-L, Noise trading and takeovers, RAND Journal of Economics, 1991,22 , p. 54

- DOI: https://doi.org/10.2307/2601007

28. Legeais, D.: Juris-classeur Comm.Fasc. 534 
29. Listokin, Y.: Management always wins the close ones, American law and Economics Review, 2008, 10, p. 159

- DOI: https://doi.org/10.1093/aler/ahn010

30. Magnier, V.: Comparative corporate governance. Legal Perspectives, Elgar ed., 2017

31. Magnier, V.: La démocratie actionnariale, D. 2007, p.x

32. Millard E., Hauriou et la théorie de l'institution, Droit et société, 30-31, 1995, p. 381

- DOI : https://doi.org/10.3406/dreso.1995.1343

33. Millon in Vasudev, P.M; Watson, S,: Corporate governance after the financial crisis, Edward Elgar, 2012

34. Mowshowitz, A.: Computers and the myth of neutrality, Proceedings on the ACM $12^{\text {th }}$ annual computer science conference on SIGCSE symposium, 1984, p. 85

- DOI: https://doi.org/10.1145/800014.808144

35. Noland, M. et alii: The political economy of cross-border voting in Europe, Columbia Journal of European law, 2009, 16, p.1

36. Smith, N.: The new urban frontier: gentrification and the revanchist city, Psychology press, 1996

37. Szabo, N.: Smart contracts, 1994 [http://Szabo.best.vwh.net/smart.contracts. html]

38. Van der Elst, Ch.; Lafarre, A.: Bringing the AGM to the 21st Century: Blockchain and Smart Contracting Tech for Shareholder Involvement, European Corporate Governance Institute (ECGI), 2017- Law Working Paper No. 358/2017 15.

39. Yermack, D.: 'Corporate governance and Blockchain', 2016, Working Paper No. w21802 NBER 1

40. Yeung, K.: Regulation by Blockchain: The Emerging Battle for Supremacy between the Code of Law and Code as Law (July 2, 2018). Modern Law Review, Forthcoming. [https://ssrn.com/abstract=3206546]

41. Winner, L.: Do artifacts have politics?, Daedelus, 1980, p. 121.

42. Wright, A.; De Filippi, P.: Decentralized Blockchain technology and the rise of Lex Cryptographia, 2015, unpublished paper, [ssrn.com/abstract=2580664]

43. OECD Principles of corporate governance, 2014 version, [www.oecd.org/corporate/2014-review-oecd-corporate-governance-principles.html. 


\section{ONLINE SOURCES}

1. [https://github.com/ethereum/wiki/wiki/White-Paper], accessed on 28/08/2018.

2. [https://bitcoin.org/bitcoin.pdf], accessed on 28/08/2018.

3. [https://harvardmagazine.com/2000/01/code-is-law-html], accessed on 28/08/2018.

4. [https://ieeexplore.ieee.org/abstract/document/7573685/], accessed on 28/08/2018.

5. [http://klsn.io], accessed on 28/08/2018.

6. [http://fortune.com/2017/08/01/blockchain-shareholders-law], accessed on 28/08/2018.

7. [https://www.globalcustodian.com/thought-leadership/future-proxy-voting/], accessed on 28/08/2018. 